Volume 5 Number 1, January-June 2021: pg. 11-22.

Fakultas Hukum, Universitas Lampung,

Bandar Lampung, Lampung, Indonesia.

E-ISSN: 2598-3105 P-ISSN: 2723-2581

http://jurnal.fh.unila.ac.id/index.php/cepalo

\title{
THE SIGNIFICANCE OF AGREEMENTS THAT ARE QUALIFIED AS FRAUD CRIME
}

\section{Joko Sriwidodo}

The Faculty of Law, Universitas Jayabaya, Email: jokosriwidodo@ gmail.com

Submitted: November 24, 2020; Reviewed: January 6, 2021; Accepted: February 8, 2021

DOI: 10.25041/cepalo.v5no1.2135

\begin{abstract}
An agreement is a legal act in which a person promises to another person or more or in which two people promise to carry out something, as is also stated in Article 1313 of the Civil Code. Contract cases are the civil case domain, but they can become criminal offenses if what is promised is fictitious or a lie. However, the reality is that currently, in practice, many practitioners are confusing it so that the reporting party criminally reports many cases of this Agreement. The purpose of this research is to find out to what extent a case agreement can be reported criminally. The problems studied in this study are: (1) what is the significance of an agreement according to Indonesian Law? (2) what is the significance of an agreement as a criminal offense of fraud? In this research, the researcher provides an overview of the Agreement's significance according to national law and the meaning of the Agreement as a criminal offense of fraud, as we know that an agreement is a civil case domain but can be included in a criminal case if the elements as mentioned above are fulfilled. In Article 378 of the Criminal Code, as happened in the case of default as stated in the Supreme Court Jurisprudence No. $1689 \mathrm{~K} / \mathrm{Pid} / 2015$, which gave a verdict that the defendant had violated Article 378 of the Criminal Code jo. 55 paragraph (1) of the Criminal Code. This research is normative legal research conducted through library research by conducting studies and analyzing primary, secondary, and tertiary legal materials. And in writing this research, too, the researcher carried out observational activities of the practices carried out in the field.
\end{abstract}

Keywords: Agreement, Default, and Fraud.

\section{A. Introduction}

The definition of an agreement is a legal action where a person promises to another person or where the two people promise each other to carry out something (according to Article 1313 of the Civil Code). This AgreementAgreement's meaning lies only in the field of assets, meaning something that can be valued in money. The Agreement is one of the engagement sources, regulated in book III of the Civil Code entitled "about the engagement" (Van verbintenis). ${ }^{1}$ The Agreement is a translation of the Dutch language, namely

\footnotetext{
1 Niru A Sinaga, "PERANAN ASAS-ASAS HUKUM PERJANJIAN DALAM MEWUJUDKAN TUJUAN PERJANJIAN," Binamulia Hukum 7, no. 2 (2018): 107-120, 110.
} 
Oveerencomsten, and sometimes translated as Agreement. Simultaneously, the bond comes from the Dutch language, namely Verbintenis, which is sometimes translated legally. ${ }^{2}$ An engagement (verbintenis) is a legal relationship between two parties in the property field. The other party demands the rights of something from the other party, and the other party must fulfill what obligations the other party demands. ${ }^{3}$

In the case of an agreement, if an obligation of the debtor to complete an achievement is not fulfilled after it has been agreed in an agreement and the obstruction of the achievement is not due to a compelling condition or condition (force majeure) ${ }^{4}$, then the debtor is deemed to have defaulted (broken promise) ${ }^{5}$ It is said that the achievement, according to Setiawan, is because it does not fulfill the achievement at all, or it is too late to fulfill the achievement or fulfill the achievement, but it is not appropriate. ${ }^{6} \mathrm{M}$. Yahya Harahap said that default means not carrying out an obligation on time or doing the obligation but not correctly. ${ }^{7}$ According to Subekti, Default is negligence or negligence of a debtor, which can be in four types, namely: ${ }^{8}$

1. Not doing what they were expected to do;

2. Performed what he promised, but partially;

3. Fulfilling task, but too late; or

4. Not fulfilling at all.

Meanwhile, fraud is a crime that has an object against the property. ${ }^{9}$ Tindak, the crime of fraud, is regulated in chapter XXV and stretches between articles 378 and 395 of the Criminal Code, ${ }^{10}$ So that in the Criminal Code, the criminal act of fraud is a criminal act with the most extended discussion among crimes against other assets. The more sophisticated and modern technology, new modes of crime are also developing, including the emergence of new forms of fraud, such as fraud via SMS, fraud under the guise of prize coupons, and others. The Criminal Code has not covered the crime, but other laws and regulations have been made to regulate it, for example, the enactment of the ITE Law and others.

Default is the civil Lawlaw domain and should not be replaced by accusing someone of defaulting based on criminal Law. ${ }^{11}$ However, many practitioners cannot distinguish between default and fraud, so that many cases of default are reported criminally.

In a payable agreement, there is a civil relationship between the debtor and the creditor in principle. ${ }^{12}$ If the indebted party then violates the promise to return the money, this is a breach of promise (default). This default can occur because of 4 things: $^{13}$

\footnotetext{
2 Hartana, "HUKUM PERJANJIAN (DALAM PERSPEKTIF PERJANJIAN KARYA PENGUSAHAAN PERTAMBANGAN BATUBARA)", Jurnal Komunikasi Hukum, vol. 2 no. 2 (2016): 147-182, 159, DOI: $10.23887 /$ jkh.v2i2.8411.

${ }^{3}$ Joko Sriwidodo dan Kristiawanto, Memahami Hukum Perikatan (Yogyakarta: Kepel Press, 2020).

${ }^{4}$ Niewenhius, Polak dalam Agus Yudha Hernoko, Hukum Perjanjian, Asas Proporsionalitas Dalam Kontrak Komersil (Jakarta: Kencana, 2011), 18. See also Sugirhot Marbun, et al. "PERBEDAAN ANTARA WANPRESTASI DAN DELIK PENIPUAN DALAM HUBUNGAN PERJANJIAN", USU Law Journal 3, no. 2 (2015): 126-137, 126

${ }^{5}$ Yahman, Karakteristik Wanprestasi dan Tindak Pidana Penipuan Yang Lahir Dari Hubungan Kontraktual (Jakarta: Prestasi Pustakaraya, 2011), 77. See also Sugirhot Marbun et al, Ibid., 126.

${ }^{6}$ Setiawan, Pokok-Pokok Hukum Perikatan (Bandung: Binacipta, 1994), 18.

${ }^{7}$ M. Yahya Harahap, Segi-Segi Hukum Perjanjian (Bandung: Alumni, 1986), 60.

${ }^{8}$ R. Subekti, Hukum Perjanjian (Bandung: Intermasa, 1979), 45

9 Dudung Mulyadi, "UNSUR-UNSUR PENIPUAN DALAM PASAL 378 KUHP DIKAITKAN DENGAN

JUAL BELI TANAH”, Jurnal Galuh Justisi 5, no. 2 (2017): 206-223, 210, DOI: 10.25157/jigj.v5i2.798.

${ }_{10} \mathrm{Ni}$ Komang Ratih Kumala Dewi, "TINDAK PIDANA PENIPUAN DENGAN MENGGUNAKAN SARANA TELEKOMUNIKASI (HANDPHONE)", Jurnal Advokasi FH UNMAS 7, no. 2 (2017): 245-256, 250.

${ }^{11}$ Sugirhot Marbun, Op.Cit., 127.

${ }^{12}$ Yusmita, Riski Pebru Ariyanti, Enricho Duo Putra Njoto, Rizal Yudistira, "PERLINDUNGAN HUKUM TERHADAP DEBITUR DAN KREDITUR DALAM MELAKUKAN PERJANJIAN BAKU”, DIH: Jurnal Ilmu Hukum 15, no. 1 (2019): 59-67,64.
} 
1. Performing things that should not be done based on the Agreement;

2. Late in fulfilling obligations;

3. Performing obligations (for example, payment) but still insufficient or only partially; or

4. Not fulfilling obligations at all.

Meanwhile, fraud is an act as regulated in Article 378 of the Criminal Code in Chapter XXV concerning Fraudulent Acts. ${ }^{14}$ Based on the formulation of the article, the elements in the act of fraud are: ${ }^{15}$

1. To benefit oneself by breaking the Law;

2. Moving people to hand over something or to give a debt or write off receivables;

3. Using any of the attempts or means of deception (using false names, fake dignity, tricks, a series of lies).

In cases related to an agreement's existence, it must be known whether the intention to commit a crime using a false name, deception or a series of lies existed from the beginning before the Agreement was made (or the money was handed over). If there is a violation of the obligations in the Agreement after the Agreement is made, then it is a default. ,The case contained in the decision of the Supreme Court No. $1689 \mathrm{~K} / \mathrm{Pid} / 2015$ explains that an agreement can be punished if it meets the elements of fraud as regulated in Article 378 of the Criminal Code. The case has gone through the judicial process from below, namely the North Jakarta District Court ruling on 10 June 2015 No. 382/Pid.B/2015/PN.Jkt.Utr also has the Bandung DKI Jakarta High Court decision dated 1 September 2015 No. 188/PID/2015/PT.DKI, until the Supreme Court decision No. 1689 K/Pid/2015. All of which gave verdicts that the defendant violated Article 378 of the Criminal Code in conjunction with Article 55 paragraph (1) to the first Criminal Code. In the ruling, the North Jakarta District Court and PT DKI Jakarta sentenced to imprisonment for 2 (two) years, but in the Supreme Court appeal to 1 (one) year 6 (six) months, by giving reasons that the defendant had I'tikad either by paying a portion and making three affidavits. So through this article, the author wants to explain when an agreement is called default and when an agreement is called fraud. Based on the description above, the following problems can be formulated as follows: What is the significance of an agreement according to Indonesian Law? And what is the significance of an agreement as a criminal offense of fraud?

This research is normative law research using normative case studies in legal behavior products, for example, reviewing the Law. Normative legal research methods or literature law research methods are methods or methods used in legal research, carried out by examining existing library materials. ${ }^{16}$ The first stage of normative legal research aims to obtain objective Law (legal norms), namely by researching legal issues. The second stage of normative legal research aims to obtain subjective Law (rights and obligations). ${ }^{17}$ The study's subject is the Law conceptualized as norms or rules that apply in society and become a reference for everyone's behavior. Normative legal research focuses on the inventory of

\footnotetext{
${ }^{13} \mathrm{https}$ //strategihukum.net/ketika-transaksi-perdata-jadi-pidana-2-2, accessed on September 28, 2020.

14 M Rendi Aridhayandi, "KAJIAN TENTANG PENERAPAN SANKSI PIDANA TERHADAP PELAKU YANGMELAKUKAN PERBUATAN CURANG DALAM BISNIS DIHUBUNGKAN DENGAN PASAL 379A KITAB UNDANG-UNDANG HUKUM PIDANA", Dialogia Iuridica: Jurnal Hukum Bisnis dan Investasi 8, no. 2 (2017): 89-92, 85, DOI: 10.28932/di.v8i2.725.

${ }^{15}$ Dhaniar Eka Budiastanti, "PERLINDUNGAN HUKUM TERHADAP KORBAN TINDAK PIDANAPENIPUAN MELALUI INTERNET”, Jurnal Cakrawala Hukum 8, no.1 (2017): 22-32, 24.

16 Soerjono Soekanto, Sri Mamudji, Penelitian Hukum Normatif Suatu Tinjauan Singkat, Cetakan ke - 11. (Jakarta: Raja Grafindo Persada, 2009), 13-14.

${ }^{17}$ Hardijan Rusli, "Metode Penelitian Hukum Normatif: Bagaimana?", Law Review Fakultas Hukum Universitas Pelita Harapan 5, no. 3 (2006): 50.
} 
positive Law, legal principles and doctrines, legal discovery in inconcreto cases, legal systematic, level of synchronization, comparative Law, and legal history. ${ }^{18}$

The approach method in this research is the statutory regulation approach (statue approach). ${ }^{19}$ Normative research certainly has to use a statutory approach because what will be examined are various legal rules that become the focus and central theme of a study. While the data analysis carried out in this study was carried out with a more qualitative approach, namely revealing as much data (legal material) as possible so that the issues raised were more transparent. The qualitative approach allows the researcher to elaborate the data obtained comprehensively and the description results to be more accountable.

This research is descriptive, which describes the symptoms in the community towards a case under study. The approach taken is a qualitative approach, which is a research methodology that produces descriptive data. ${ }^{20}$ The author uses a qualitative approach to understand or understand the symptoms of research. ${ }^{21}$ The author conducts research to draw legal principles (rechsbeginselen) that can be carried out on written positive Law and unwritten positive Law. ${ }^{22}$

\section{B. Discussion}

\section{The Definition of Agreement according to the Indonesian Law}

As stated in the Indonesian Dictionary, the meaning of the word agreement is "written or oral agreement made by two or more parties, each of which agrees to comply with what is stated in the agreement". ${ }^{23}$ Whereas in the explanation of the Legal Dictionary that the word agreement is "an agreement made by two or more parties, written or oral, each of which agrees to obey the contents of the agreement that has been made jointly." According to Article 1313 of the Civil Code, "An agreement is an act with one or more people binding himself to one or more people". 24

Civil law experts generally think that the Agreement's definition in the regulatory provisions is incomplete and too broad. Incomplete in the sense that because it is only about a one-sided agreement and is said to be broad because it can include matters concerning the marriage promise, namely actions in the field of family law that give rise to an agreement, namely the promise to love each other, etc. However, it is unique because it is regulated in separate provisions so that Book III of the Civil Code does not directly apply to it. It also includes acts against the Law, whereas in this action against the Law there is no Agreement. ${ }^{25}$

Meanwhile, the meaning of an engagement is a legal relationship between two parties. On the one hand, there are rights, and on the other hand, there are obligations. ${ }^{26}$ According to Sudikno, an agreement is a legal relationship based on an agreement to have legal consequences. $^{27}$ Another opinion was expressed by Rutten as quoted by Prof. Purwahid Patrik, which states that an agreement is an act that occurs under the formalities of existing legal regulations depending on the conformity of the wishes of two or more people who are

\footnotetext{
${ }^{18}$ Abdul Kadir Muhammad. Hukum dan Penelitian Hukum (Bandung: Citra Aditya Bakti. 2004), 52

${ }^{19}$ Peter Mahmud Marzuki, Penelitian Hukum. Cet2. (Jakarta: Kencana. 2008), 29.

${ }^{20}$ Soerjono Soekanto, Pengantar Penelitian Hukum, (Jakarta: UI Press, 198632.

${ }^{21}$ Ibid.

22 Ibid., 252.

${ }^{23}$ Departemen Pendidikan Nasional, Kamus Besar Ikthasar Indonesia (Jakarta: Balai Pustaka, 2005), 458.

${ }^{24}$ Sudarsono, Kamus Hukum (Jakarta: Rineka Cipta, 2007), 363

${ }^{25}$ Mariam Darus, KUH Perdata Buku III Hukum Perikatan dengan Penjelasan (Bandung: Alumi, 2005$), 89$.

${ }^{26}$ J. Satrio, Perikatan yang Lahir dari Perjanjian, Buku 1 (Bandung: Citra Aditya Bakti, 1995), 5.

27 Hananto Prasetyo, "PEMBAHARUAN HUKUM PERJANJIAN SPORTENTERTAINMENTBERBASIS NILAI KEADILAN(Studi Kasus Pada Petinju Profesional di Indonesia)”, Jurnal Pembaharuan Hukum 4, no. 1 (2017): 65-81, 67, DOI: 10.26532/jph.v4i1.1645.
} 
intended to arise legal consequences from the interests of one party at the expense of the other party or for the benefit of each party reciprocally. ${ }^{28}$ The term agreement is often equated with the term contract, although several law scholars distinguish the two terms. When returning to statutory regulations as listed in Chapter II of the Third Book of the Civil Code entitled "An Engagement Born from a Contract or Agreement", it is clear that the Law provides a parallel definition between contract and Agreement.

Based on the provisions contained in Chapter II Book III of the Civil Code, it can be said that the meaning of Agreement and contract can be said to be more or less the same. Thus all provisions related to contract law also apply in contract law. So in this provision, the author agrees with the meaning stated in Chapter II of the Third Book of the Civil Code. For this reason, in this research, the word "agreement" is used to represent the words of an agreement or contract, especially an agreement that is accompanied by default (broken promise). R. Subekti stated that the Agreement is "an agreement is a legal relationship between two or more people, based on which one party has the right to demand something from the other party, and the other party is obliged to fulfill the demand". ${ }^{29}$ According to Salim HS, an agreement is a "legal relationship between one subject and another in the field of assets, where one legal subject is entitled to achievement and as well as other legal subjects are obliged to carry out their achievements following what has been agreed". ${ }^{30}$

According to Niewenhius' opinion, an agreement is the primary means for the parties to independently determine and regulate legal relations. In contrast, according to Polak, an agreement is nothing but an agreement that creates rights and obligations for the parties bound in it. ${ }^{31}$ Furthermore, according to private Law, an agreement is an act whereby one or more people bind themselves to one other person/more (Article $1313 \mathrm{BW}$ ). This understanding is as we have also mentioned above. In understanding this Agreement contains several elements:

a. Actions, the use of the word "act" in the formulation of this Agreement is more appropriate if it is replaced by the word legal action or legal action because the act brings legal consequences for the parties who agreed;

b. One person or more against one or more other people. For the existence of an agreement, at least two parties face each other and give statements that match each other. A party is a person or legal entity.

c. Binding, In the Agreement, there is an element of the promise given by one party to the other. In this Agreement, people are bound to the legal consequences that arise because of their own will.

Meanwhile, according to the provisions of Public Law, the Agreement refers to the International Agreement. International treaties currently play a significant role in regulating citizens' lives and interactions in the international community. International treaties are essentially the main source of Law for the international community to regulate countries or other international legal subjects' activities. Until 1969, the making of international treaties was only regulated by customary Law or customary Law, only according to a country's customs. Based on the draft articles prepared by the Internatiprimary Law Commission, an International Conference was held in Vienna from 26 March to 24 May 1968 and from 9 April-22 May 1969 to codify the customary Law. The conference then gave birth to the Vienna Convention on the Law of Treaties, signed on 23 May 1969. This Convention entered

\footnotetext{
${ }^{28}$ Purwahid Patrik, Hukum Perdata II, Perikatan yang Lahir dari Perjanjian dan Undang-undang (Semarang: FH UNDIP, 1988), 1-3.

${ }^{29}$ Retna Gumanti, "SYARAT SAHNYA PERJANJIAN (Ditinjau Dari KUHPerdata)", Jurnal Pelangi Ilmu 5, no. 1 (2015): 1-13, 3,

${ }^{30}$ Salim MS, Hukum Kontrak, Teori \& Tekriik Penyusunan Kontrak (Jakarta: Sinar Grafika, 2008), 27.

31 Niewenhius, Polak in Agus Yudha Hernoko, Hukum Perjanjian, Asas Proporsionalitas Dalam Kontrak Komersil (Jakarta: Kencana, 2011), 18.
} 
into force on 27 January 1980 and is a positive international law. Article 2 of the 1969 Vienna Convention defines an international treaty (treaty) as an agreement made between countries in writing and governed by international Law, whether in a single instrument or two or more related instruments and whatever name is given to it. The definition of the international Agreement above contains elements:

a. The existence of international legal subjects, namely states, international organizations, and liberation movements. The state's recognition as a subject of international Law that has the full capacity to conclude international treaties is contained in Article 6 of the Vienna Convention. International organizations are also recognized as parties that make agreements with the will's conditions to make agreements originating from member countries. The international agreements that are made are the area of the international organization's authority. These restrictions are seen in Article 6 of the Vienna Convention. The capacity of liberation movements is recognized but is selective and limited. Selective means that these movements must be recognized in advance by the region where the movement is located. Limited means that participation in the Agreement is to carry out the desire of the movement to establish an independent state

b. International legal regime. International treaties must be subject to international Law and may not be subject to specific national laws. Even though a state or international organization makes the Agreement, if it has been subject to specific selected national laws, the Agreement is not an international agreement.

So the meaning of an agreement according to the provisions of national Law is a legal act in which a person promises to another person or more, or where two or more people promise each other to carry out a thing, according to article 1313 of the Civil Code.

\section{The Significance of Agreements that are Qualified as Fraud Crime}

The concept of an agreement is a civil relationship regulated in the Burgelijk Wetboek (BW) of the Civil Code. If the person who promises does not fulfill the predetermined promise, then based on Article 1365 of the Civil Code, that person can be said to have committed default or breach of contract. However, many people are reported to the police for not fulfilling the promises stipulated in an agreement in practice. However, in general, the reporting party feels that the person has deceived the reporter because the promise to be carried out has not been fulfilled, even though the reporter has delivered goods and/or money to that person. This condition raises legal problems when someone who does not fulfill an agreement can be said to have defaulted so that the case's settlement must be done civilly when the person can be said to have committed fraud where the case's settlement was carried out criminally.

That the object of the Agreement is in the form of a promise that must be fulfilled and determined by the parties who agree, and the promise is an achievement in the Agreement. Achievement is an obligation that must be fulfilled or carried out by the parties following what was agreed. The form can be in the form of doing something or not doing something or giving something. ${ }^{32}$ Forgetting the promise or not fulfilling the achievement is called default. Fraud is one of the criminal acts regulated in Article 378 of the Criminal Code, in the future referred to as the Criminal Code, which contains that anyone to benefit himself or another person unlawfully uses a false name or fake dignity, with trickery. Or a series of lies, motivating other people to hand over something to him, or to give a debt or write off a debt,

\footnotetext{
${ }^{32}$ FX. Suhardana, Contract Drafting Kerangka Dasar dan Teknik Penyusunan Kontrak (Yogyakarta: Universitas Atma Jaya Yogyakarta, 2009), 12.
} 
shall be threatened with fraud with a maximum imprisonment of four years. ${ }^{33}$ Fraud and Covenant are two legal acts that are governed by two different types of laws. Cases of default in the Agreement can only be resolved through a civil court because this case is indeed the civil case domain. But in reality today, many cases of default are criminally reported.

According to Article 1328 of the Civil Code, fraud is a reason for the cancellation of the Agreement, if the deception used by one party is such that it is clear and evident that the other party does not want to make the Agreement if it is not carried out through such deception. Fraud is not suspected but must be proven. This means that someone is declared to be deceiving if they commit a trick with a series of lies/words that deceive others and force others to believe that it is true. Fraud (bedrog) is deliberately submitting a false picture or fact to agree. ${ }^{34}$ A person cheating is based on the intention to cheat. Thus someone can be said to have committed fraud if he deliberately lied by tricking other people into getting a loan of money that he realizes that he will not return the money in the future/when the deadline for the refund is due. According to Riduan Syahrani, three conditions must be met for the cancellation of the Agreement, namely: the Agreement must be reciprocal, must have defaulted, must be by a judge's decision. ${ }^{35}$

The basis for the consideration of law enforcers, both the police, prosecutors, and judges, to apply Article 378 of the Criminal Code to cases of default in the Agreement is because of the article's elements. ${ }^{36}$

a. The Police consider that there are elements of fraud in the investigation stage. These elements, namely:

1) Fake name, this element is proven by adjusting the name used in the Agreement with a valid identity or birth certificate;

2) False Dignity, this element is proven based on the suitability of the validity period and the end of the situation with the validity of the agreed Agreement;

3) Deception, this element is proven from existing evidence which is adjusted to the statements of the perpetrator and witnesses;

4) Lies, this element is proven from the inconsistency of the perpetrator's and witnesses' statements from the beginning of the birth agreement process until the evidence in court.

b. The Prosecutor's consideration of accepting the BAP submitted by the investigator is because the elements in Article 378 of the Criminal Code are complete and meet the formal and material requirements to proceed to court Formal requirements, conditions that see the completeness of the administration. While the material requirements, namely the requirements that contain all the evidence and evidence of the act and must fulfill all of the elements in Article 378 of the Criminal Code, if not proven, then the case cannot be continued.

c. Judges consider applying Article 378 of the Criminal Code in cases of default, namely because the judge has the freedom according to his belief to determine the evidence shown in court to be subject to criminal sanctions. Subjective judges can violate the principle of Law, namely the Principle of Culpability, which determines that an act cannot be convicted if there is no mistake. The impact results from the error in applying the Law subjectively, namely reducing the value of justice and legal certainty. A judge's decision based solely on conviction is ineffective if it is not supported by evidence that

\footnotetext{
${ }^{33}$ Ester Magdalena Robot, "PENERAPAN PASAL 378 KUHP TERHADAP KASUS WANPRESTASI PADA PERJANJIAN UTANG PIUTANG”, Jurnal Ilmiah Fakultas Hukum Universitas Atma Jaya Yogykarata (2014): $1-16,1$.

${ }^{34}$ Salim H. S, Hukum Kontrak Teori dan Teknik Penyusunan Kontrak (Jakarta: Sinar Grafika, 2003), 173.

${ }^{35}$ Riduan Syahrani, Seluk - Beluk dan Asas - Asas Hukum Perdata (Bandung: Alumni, 2010), 230.

${ }^{36}$ Ester Magdalena Robot, Op.Cit., 15.
} 
proves the element of fraud. The provisions of Article 183 of the Criminal Procedure Code, namely that a judge may not impose a sentence on a person unless, with at least two valid pieces of evidence, he is convinced that a criminal act has occurred and that the defendant is guilty of committing it. Accounts payable agreement that ends due to late settlement of debt is a default case, not a case of fraud. Evidence can be analyzed from the fulfilled elements. An act is said to be fraudulent if it meets the deception elements, including false names, false dignity, and a series of lies that result in creditors giving debt involuntarily or without realizing it.

d. Meanwhile, an agreement that ends because the debtor has not paid the debtor is late in paying the debtor has done things that were not agreed upon is an element of default. If a case that is reported as a crime of fraud is a case of debts that are not repaid, so that the debtor is suspected of defrauding the creditor but the evidence provided does not meet the elements as contained in Article 378 of the Criminal Code, then the correct decision to be applied is off (Onslag) of all lawsuits. This is because the Agreement is a legal act, but not a criminal act but a civil law act. This means that the legal action was born because of the Agreement of the parties to bind themselves to each other. ${ }^{37}$

An example of a case of agreement (default) using article 378 of the Criminal Code regarding fraud is the case of the Supreme Court decision No.1689 K/Pid/2015 with the defendant Henry Kurniadi. In which case, the defendant was proven to have committed a criminal act of participating in fraud against PT. Astrindo Satrya Kharisma (Astrindo Travel) was committed by the defendant from October 2013 to December 2013 by asking for help from his former employer, namely Ms. Rezky Gustinawati, an employee of PT. Astra International, one of whose duties was to order plane tickets for the benefit of the defendant and his family abroad, as if the order was from PT. Astra International, even though the defendant had stopped working from the company since July 2013, when Astrindo Satrya Kharisma asked PT. Astra Internasional, PT. Astra International refused to pay it because it had never booked the ticket, resulting in Astrindo Travel losing US \$66,316 or 803.749 .920 IDR. ${ }^{38}$ The defendant had good faith by paying part of the invoice amounting to US\$11,834 or the equivalent of 145.563.000 IDR and make two letters of acknowledgment of debt and one letter of mutual Agreement, wherein the defendant will be fully responsible for the remainder of the shortage after the apartment is sold. However, until the agreed time, the defendant cannot pay off the shortfall, and in the end, Astrindo Travel reports it to the police. In the Decision of the North, Jakarta District Court dated 10 June 2015 No. 382/Pid.B/2015/PN.Jkt.Utr which in the Decision Letter:

a. Declare that the defendant is legally and convincingly proven guilty of committing a criminal act of participating in fraud as in the first indictment, violating Article 378 of the Criminal Code in conjunction with Article 55 paragraph (1) of the Criminal Code;

b. Sentenced the defendant to imprisonment for 2 (two) years.

In the Decision on the Appeal of the DKI Jakarta High Court dated 1 September 2015 No. 188/PID/2015/PT.DKI in the Decision Letter :

a. Receiving an appeal from the Defendant's Legal Counsel;

b. Strengthening the Decision of the North Jakarta District Court on 10 June 2015 Number. 382/Pid.B/2015/PN.Jkt.Utr.

Whereas in the Supreme Court Cassation Decision dated 12 January 2016 No. 1689 K/PID/2015 in the Amar Decision:

a. Reject the Cassation Petitioner/Defendant.

\footnotetext{
${ }^{37}$ Ester Magdalena Robot, Op.Cit., 13-14.

${ }^{38}$ M. Hadi Sussilo, et.al. "Tindak Pidana Penipuan Yang Didasari Wanprestasi Dalam Perjanjian", Prosiding Seminar Nasional Humanis, (2019).
} 
b. Revise the decision of the DKI Jakarta High Court dated 1 September 2015 Number. 188/PID/2015/PT.DKI, which strengthened the decision of the North Jakarta District Court dated 10 June 2015 Number. 382/Pid.B/2015/PN.Jkt.Utr. ;

c. Menjatuhkan pidana kepada Terdakwa dengan pidana penjara selama 1 (satu) tahun 6 (enam) bulan.

As for the judex Juris' considerations on the reasons for the appeal applicant/defendant, namely: ${ }^{39}$

a. However, the defendant's cassation reasons cannot be justified because the Judex Facti did not apply the Law incorrectly in trying the defendant. The decision of the Jakarta High Court Number: 188/Pid/2015/PT.DKI dated 1 September 2015, which strengthens the North Jakarta District Court Number 382/Pid.B/2015/PN's decision.Jkt., dated 10 June 2015 , found the defendant guilty of committing a criminal act of participating in fraud as the Public Prosecutor's first indictment was made based on correct legal considerations. The defendant was proven to have committed fraud against PT. Astrindo Satrya Kharisma (Astrindo Travel) which was carried out by the defendant by asking for help from Rezky Gustinawati, an employee of PT Astra International whose one of the duties was to order plane tickets for the benefit of the defendant and his family, as if the order was from Astra International so that when Astrindo Satrya Kharisma won money for ordering the tickets to PT Astra International, PT Astra International refused to pay it because it had never booked the ticket, so Astrindo Travel suffered a loss of US\$ 66.316. or equivalent to 803.749.920 IDR;

b. Whereas the reason for the defendant's cassation stating that the defendant's case is not a criminal case, but a subsequent civil case of debit and credit, between the Defendant and Astrindo Travel cannot be justified because the defendant in ordering the ticket has used a false name or position, civil law relationship that is not based on honesty, and evil intentions to harm others is a fraud;

c. Whereas the decision of the Jakarta High Court Number: 188/PID/2015/PT.DKI dated 1 September 2015, which strengthens the North Jakarta District Court Number: 382/Pid.B/2015/PN.Jkt.Utr dated 10 June 2015 must be corrected only regarding the length of the sentence imposed because the defendant has paid part of his debt and made a Debt Statement on the debt to be repaid;

It can be seen in this case that the defendant initially had good faith by paying the US \$ 11,834 and making two debt acknowledgment letters and one collective agreement letter, the contents of which the defendant was entirely responsible for the remaining debt deficiency and would pay it after his apartment sold. However, up to the time promised, the defendant was unable to pay off the shortfall. In this case, the fraud element is fulfilled so that the defendant is threatened with a penalty of 1 (one) year and 6 (six) months. From here, the meaning of an agreement that can qualify as a criminal offense of fraud is when the Agreement is fulfilled the element of fraud, as also happened in the case described above. First, the defendant had good faith by paying part of the receivable and making three statements but was unable to pay off the remaining shortfall at the agreed time. So that in this case, the age of fraud is met.

\section{Conclusion}

Whereas the meaning of an agreement according to the provisions of national Law is as stated in Article 1313 of the Civil Code, which reads, "a legal act in which a person promises to another person or more, or where two or more people promise to do something". This

\footnotetext{
${ }^{39}$ Ibid.
} 
provision is the concrete meaning of an agreement according to the provisions of National Law.

The meaning of an agreement that can qualify as a criminal offense of fraud is when an agreement fulfills the fraudulent elements mentioned in Article 378 of the Criminal Code, namely fulfilling the elements; Fake names, fake dignity, wiles, and lies. Likewise, what happened in the case outlined in the Supreme Court Jurisprudence No. $1689 \mathrm{~K} / \mathrm{Pid} / 2015$, which gave the verdict on the cassation of the criminal fraud case with the defendant Henry Kurniadi and the Astrindo Travel reporter. Initially, the case was an interpretation that was the domain of a civil case but was reported criminally because it fulfilled the fraud element, which fulfilled the elements of a false name or fake dignity.

It is necessary to clarify the meaning of the Agreement regulated in the provisions of laws and regulations to not cause overlapping between legal rules. The public needs to understand when an agreement is categorized as default and when an agreement is categorized as a criminal offense of fraud.

\section{REFERENCES}

\section{A. Journal \& Research Paper}

Aridhayandi, $M$ Rendi. "KAJIAN TENTANG PENERAPAN SANKSI PIDANA TERHADAP PELAKU YANGMELAKUKAN PERBUATAN CURANG DALAM BISNIS DIHUBUNGKAN DENGAN PASAL379A KITAB UNDANG-UNDANG HUKUM PIDANA", Dialogia Iuridica: Jurnal Hukum Bisnis dan Investasi 8, no. 2 (2017): 89-92, DOI: 10.28932/di.v8i2.725.

Budiastanti, Dhaniar Eka. "PERLINDUNGAN HUKUM TERHADAP KORBAN TINDAK PIDANAPENIPUAN MELALUI INTERNET”. Jurnal Cakrawala Hukum 8, no. 1, 2017: 22-32.

Bukido, Rosdalina. "URGENSI PERJANJIAN DALAM HUBUNGAN KEPERDATAAN," Jurnal Ilmiah Al-Syir'ah 7, no. 2, 2009: 1-22, DOI: 10.30984/as.v7i2.42.

Dewi, Ni Komang Ratih Kumala "TINDAK PIDANA PENIPUAN DENGAN MENGGUNAKAN SARANA TELEKOMUNIKASI (HANDPHONE)", Jurnal Advokasi FH UNMAS, vol. 7 no. 2 (2017): 245-256, 250.

Gumanti, Retna. "SYARAT SAHNYA PERJANJIAN (Ditinjau Dari KUHPerdata)", Jurnal Pelangi Ilmu 5, no. 1, 2015: 1-13.

Hartana. "HUKUM PERJANJIAN (DALAM PERSPEKTIF PERJANJIAN KARYA PENGUSAHAAN PERTAMBANGAN BATUBARA)". Jurnal Komunikasi Hukum 2, no. 2, 2016: 147-182, DOI: 10.23887/jkh.v2i2.8411.

Marbun, Sugirhot et al. "PERBEDAAN ANTARA WANPRESTASI DAN DELIK PENIPUAN DALAM HUBUNGAN PERJANJIAN." USU Law Journal 3, no. 2, 2015: 126-137.

Mulyadi, Dudung. "UNSUR-UNSUR PENIPUAN DALAM PASAL 378 KUHP DIKAITKAN DENGAN JUAL BELI TANAH". Jurnal Galuh Justisi 5 no. 2, 2017: 206-223, DOI: $10.25157 /$ jigj.v5i2.798.

Prasetyo, Hananto. "PEMBAHARUAN HUKUM PERJANJIAN SPORTENTERTAINMENTBERBASIS NILAI KEADILAN (Studi Kasus Pada Petinju Profesional di Indonesia)". Jurnal Pembaharuan Hukum 4, no. 1, 2017: 65-81, DOI: 10.26532/jph.v4i1.1645.

Robot, Ester Magdalena. "Penerapan Pasal 378 KUHP Terhadap Kasus Wanprestasi Pada Perjanjian Utang Piutang”, Jurnal Ilmiah Fakultas Hukum Universitas Atma Jaya, 2014. 
Rusli, Hardijan. "Metode Penelitian Hukum Normatif: Bagaimana?", Law Review Fakultas Hukum Universitas Pelita Harapan 5, no. 3, 2006.

Sinaga, Niru A. "PERANAN ASAS-ASAS HUKUM PERJANJIAN DALAM MEWUJUDKAN TUJUAN PERJANJIAN." Binamulia Hukum 7, no. 2, 2018: 107120.

Sussilo, M. Hadi, et.al. "TINDAK PIDANA PENIPUAN YANG DIDASARI WANPRESTASI DALAM PERJANJIAN". Prosiding Seminar Nasional Humanis, 2019.

Yusmita, Riski Pebru Ariyanti, Enricho Duo Putra Njoto, Rizal Yudistira, "PERLINDUNGAN HUKUM TERHADAP DEBITUR DAN KREDITUR DALAM MELAKUKAN PERJANJIAN BAKU”, DIH: Jurnal Ilmu Hukum 15, no. 1, 2019: 5967.

\section{B. Book}

Badruzzaman, Mariam Darus. KUH Perdata Buku III Hukum Perikatan Dengan Penjelasan, Bandung: Alumni, 2005.

Departemen Pendidikan Nasional. Kamus Besar Ikhtisar Indonesia, edisi ketiga, Jakarta: Balai Pustaka, 2005.

H. S, Salim. Hukum Kontrak Teori dan Teknik Penyusunan Kontrak. Jakarta: Sinar Grafika, 2008.

H. S, Salim. Hukum Kontrak Teori dan Teknik Penyusunan Kontrak. Jakarta: Sinar Grafika, 2003.

Harahap, M. Yahya. Segi-Segi Hukum Perjanjian. Bandung: Alumni, 1986.

Hernoko, Agus Yudha. Hukum Perjanjian, Asas Proporsionalitas Dalam Hukum Kontrak Komersil. Jakarta: Kencana, 2011.

Marzuki, Peter Mahmud. Penelitian Hukum. Jakarta: Kecana, 2008.

Muhammad, Abdulkadir. Hukum dan Penelitian Hukum. Bandung: Citra Aditya Bakti, 2004.

Patrik, Purwahid. Hukum Perdata II, Perikatan Yang Lahir Dari Perjanjian dan UndangUndang. Semarang: Fakultas Hukum Universitas Diponegoro, 1988.

Satrio, J. Perikatan Yang Lahir Dari Perjanjian Buku I. Bandung: Citra Aditya Bakti, 1995.

Setiawan. Pokok-Pokok Hukum Perikatan. Bandung: Binacipta, 1994.

Soekanto, Soejono. Pengantar Penelitian Hukum. Cet. 2. Jakarta: Universitas Indonesia Press, 2007.

Soekanto, Soerjono \& Sri Mamudji. Penelitian Hukum Normatif Suatu Tinjauan Singkat,Cetakan ke - 11. Jakarta : Raja Grafindo Persada, 2009.

Sriwidodo, Joko., Kristiawanto. Memahami Hukum Perikatan. Yogyakarta: Kepel Press, 2020.

Subekti, R. Hukum Perjanjian. Bandung: Intermasa, 1979.

Sudarsono. Kamus Hukum. Jakarta: Rineka Cipta, 2007.

Sudikno. Ilmu Hukum. Yogyakarta: Penerbit Liberty, 2008.

Suhardana, F.X. Contract Drafting, Kerangka Dasar dan Teknik Penyusunan Kontrak. Yogyakarta: Universitas Atma Jaya, 2009.

Syahrani, Riduan. Seluk-Beluk dan Asas-Asas Hukum Perdata. Bandung: Alumni, 2010.

Yahman. Karakteristik Wanprestasi dan Tindak Pidana Penipuan Yang Lahir Dari hubungan Kontraktual. Jakarta: Prestasi Pustakajaya, 2011.

\section{Internet}

https://strategihukum.net/ketika-transaksi-perdata-jadi-pidana-2-2 diakses tanggal 28 September 2020 jam 21:45 
